\title{
Slc11a1 (formerly Nramp1) and susceptibility to canine visceral leishmaniasis
}

\author{
Elisenda SAnchez-Robert*1 ${ }^{* 1}$, Laura Altet ${ }^{1}$, Mireia Utzet-SAdurni ${ }^{2}$, \\ Urs GIGER ${ }^{3}$, Armand SANCHEZ ${ }^{1}$, Olga FRANCINO ${ }^{1}$ \\ ${ }^{1}$ Veterinary Molecular Genetics Service, Department of Animal and Food Science, Veterinary Faculty, \\ Universitat Autonoma de Barcelona, 08193 Bellaterra, Barcelona, Spain \\ 2 Population Genomics Node, National Institute for Bioinformatics, Biomedical Research Park, \\ 08003 Barcelona, Spain \\ ${ }^{3}$ Section of Medical Genetics, School of Veterinary Medicine, University of Pennsylvania, 3900 Spruce Street, \\ Philadelphia, PA 19104-6010 USA
}

(Received 26 July 2007; accepted 18 February 2008)

\begin{abstract}
Visceral leishmaniasis is the most important zoonosis in Europe and it is caused by Leishmania infantum, a protozoan intracellular parasite. Canine visceral leishmaniasis (CVL) is endemic in the Mediterranean basin, Middle East, and South America, and is emerging within non endemic areas such as the United Kingdom and North America. We have analyzed 24 polymorphisms in the canine Slc11al (formerly NRAMP1) gene: 19 new polymorphisms characterized by direct sequencing from 40 dogs of different breeds and five polymorphisms previously described. Data analysis in a case-control study including 164 dogs of 19 different breeds revealed that two of the 24 polymorphisms were associated with increased risk for CVL: one intronic single nucleotide polymorphism (SNP) (A4549G in intron 6: odds ratio $(\mathrm{OR})=6.78, P=0.001$ ) and one silent SNP in exon 8 (C4859T: OR $=13.44, P=0.004)$. In silico analysis of the significant SNP revealed that SNP in the promoter region affect putative transcription binding sites and SNP C4859T in exon 8 disrupts a putative exonic splicing enhancer (ESE). These results corroborate that Slc1 lal polymorphisms are associated with increased risk for CVL.
\end{abstract}

leishmaniasis / Slc11a1 / polymorphism / dog / susceptibility

\section{INTRODUCTION}

Infection is one of the leading causes of human mortality and morbidity particularly in children and in third world countries (World Health Organization). Infections with HIV, Mycobacteria, Malaria, and Leishmania have been most commonly studied [4]. Leishmania is a protozoan intracellular parasite and transmitted by sandflies. The domestic dog is also susceptible to Leishmania infection, which results in great morbidity and mortality among dogs and is considered the main peridomestic reservoir of the parasite.

* Corresponding author: elisenda.sanchez@uab.cat
The zoonosis caused by Leishmania infantum (L. infantum) is known as visceral leishmaniasis. Canine visceral leishmaniasis (CVL) is endemic in the Mediterranean basin, Middle East, and South America, and the prevalence of Leishmania infection can reach 67\% in these areas [29]. Moreover, leishmaniasis is emerging within non endemic areas mostly because of transportation of dogs from endemic areas and climatic changes with expansion of the sandfly vector. Hence CVL has been reported in many countries in Europe including the United Kingdom [26] and in North America particularly in the English and American foxhounds $[8,10,18$, $21,24]$. 
Genetic factors involved in the resistance/ susceptibility of the host to CVL have been suspected, and significant correlations between major histocompatibility complex (MHC) class II and/or Slc1lal genes (solute carrier family 11a member 1; formerly NRAMP1) and CVL have been reported $[1,19,23]$. In a cohort of Brazilian mongrel dogs naturally exposed to $L$. infantum the MHC class II allele DLA-DRB $1 * 01502$ increased the risk of being parasite infected compared with dogs lacking this allele [19].

The Slcllal gene acts as a proton/divalent cation antiporter, which controls the replication of intracellular parasites by altering the intravacuolar environment of the microbecontaining phagosome [13]. Polymorphisms in the Slcllal gene have been associated with CVL in a case-control study with 97 dogs of different breeds [23]: three single nucleotide polymorphisms (SNP) in the Slcllal promoter region (T151C, A180G, G318A) were associated with increased risk for CVL in different breeds, and one haplotype was significantly associated with the Boxer breed, which may suggest varied predispositions to infectious disease among canine breeds. In fact, genetic epidemiologic surveys in dogs revealed higher prevalence of Leishmania infection (up to 25\%) in Boxers, German Shepherds, Doberman Pinschers, Cocker Spaniels, and among American and English Foxhounds (held in foxpacks in North America) [8, 11, 12, 23]. Conversely, certain canine breeds may be resistant to Leishmania infection and CVL such as the Mediterranean Ibizan Hound, an autochthonous breed from the Balearic Island of Ibiza [28].

Similarly varied susceptibility to Leishmania infection has been described between ethnic human populations [9]. Different studies showed significant associations for a $5^{\prime}(\mathrm{CA})$ repeat polymorphism in the human Slcllal promoter and visceral leishmaniasis [3, 9]. This polymorphism in the promoter affects Slc1lal expression and correlates with infectious as well as autoimmune disease susceptibility $[25,35]$. The association between Slcllal with leishmaniasis was corroborated in a Sudanese population study, where two new polymorphisms, one located in exon 3 $(274 \mathrm{C} / \mathrm{T})$ and another one located in intron $4(469+14 G / C)$ were found [2, 17]. Beyond the Slcllal polymorphism interactions with multiple other genes and candidate regions, such as MHC, IL-4, IFNGR or loci 22q12 and 2q23-24 have been implicated [4, 9]. Studies with canine and murine disease models are necessary to further advance our knowledge of the molecular basis of Leishmania infection and disease predisposition or resistance. Such studies could help humans and dogs alike who are experiencing a high degree of morbidity and mortality from leishmaniasis.

Our aim was to corroborate the association of Slcllal gene with CVL by fully characterising sequence variation and typing it in an extended case-control cohort. A total of 24 polymorphisms of the Slcllal gene have been typed in 164 dogs from 19 different breeds: 19 new polymorphisms that have been discovered by direct sequencing of 40 dogs from 11 different breeds and 5 polymorphisms previously described [23]. Polymorphism has been also analyzed in a cohort of 58 Ibizan Hounds, a breed described as resistant to CVL [28].

\section{MATERIALS AND METHODS}

\subsection{Animal cohort and DNA extraction}

The case-control study included 164 dogs from 19 different breeds (Tab. I). All dogs were living in Spain with the exception of 12 Foxhounds from south-eastern Pennsylvania, USA. The case animals are 65 dogs that have developed clinically severe disease in which Leishmania is identified concomitantly by positive Leishmania polymerase chain reaction (PCR) and positive anti-Leishmania antibody titre. Ninety-nine healthy dogs from the same breeds and geographical regions were selected to match the case animals. The control dogs have been selected among individuals older than five years presented to veterinary hospitals for regular health checks, which have never shown signs of CVL, but would have been exposed to Leishmania organisms (endemic area). We also further examined a cohort of 58 Ibizan Hound dogs, an autochthonous breed from the Balearic Island of Ibiza (Spain) which has been described as a resistant breed to leishmaniasis [28]. 
Table I. Animals per breed included in the sequencing of the Slcllal gene for the SNP characterization (SNP), in the case-control extended cohort and in a reduced, fully matched cohort (1:1 ratio), chosen at random from the available dogs, to confirm the significant associations.

\begin{tabular}{|c|c|c|c|c|c|}
\hline \multirow[t]{2}{*}{ Breed } & \multirow[t]{2}{*}{ SNP } & \multicolumn{2}{|c|}{ Extended cohort } & \multicolumn{2}{|c|}{ Breed matched cohort } \\
\hline & & Case & Control & Case & Control \\
\hline Boxer & 5 & 12 & 23 & 12 & 12 \\
\hline German Shepherd & 1 & 9 & 20 & 9 & 9 \\
\hline Rottweiler & 1 & 2 & 14 & 2 & 2 \\
\hline Foxhound & 12 & 10 & 2 & 2 & 2 \\
\hline Siberian Husky & - & 3 & 7 & 3 & 3 \\
\hline Miniature Schnauzer & 3 & 3 & 1 & 1 & 1 \\
\hline Standard Schnauzer & - & 3 & 3 & 3 & 3 \\
\hline Doberman Pinscher & 1 & 2 & 6 & 2 & 2 \\
\hline Beagle & 7 & 4 & 3 & 3 & 3 \\
\hline Bulldog & 1 & 2 & 4 & 2 & 2 \\
\hline Cocker Spaniel & - & 2 & 4 & 2 & 2 \\
\hline Great Dane & - & 2 & 2 & 2 & 2 \\
\hline Spanish mongrel & - & 5 & 0 & - & - \\
\hline Teckel & - & 1 & 4 & 1 & 1 \\
\hline Pointer & - & 1 & 3 & 1 & 1 \\
\hline Akita Inu & - & 1 & 2 & 1 & 1 \\
\hline Alaskan Malamute & - & 1 & 1 & 1 & 1 \\
\hline Basset Hound & 1 & 1 & 0 & - & - \\
\hline German Shorthaired Pointer & 1 & 1 & 0 & - & - \\
\hline Ibizan Hound ( $\mathrm{N}=58)$ & 7 & & & & \\
\hline TOTAL & 40 & 65 & 99 & 47 & 47 \\
\hline
\end{tabular}

DNA was obtained from $0.1 \mathrm{~mL}$ of bone marrow aspirate or $0.5 \mathrm{~mL}$ of peripheral whole blood as previously described [22]. Briefly, samples were washed in buffer Tris $10 \mathrm{mM}$ pH 8.0, EDTA $1 \mathrm{mM}$ to disrupt the erythrocyte membrane until the leukocyte pellet was white. Leukocytes were then lysed by incubation of the pellet in $0.1 \mathrm{~mL}$ of lysis buffer $(50 \mathrm{mM} \mathrm{KCl}, 10 \mathrm{mM}$ Tris $\mathrm{pH} 8.0,0.5 \%$ Tween-20 and $23 \mu \mathrm{g}$ of proteinase $\mathrm{K}$ ) at $56^{\circ} \mathrm{C}$ for $5 \mathrm{~h}$. Following proteinase $\mathrm{K}$ inactivation $\left(90^{\circ} \mathrm{C}\right.$ for $10 \mathrm{~min}$ ) DNA samples were diluted in milli-Q water $(1 / 10$ for bone marrow aspirate and $1 / 5$ for blood), and $2 \mu \mathrm{L}$ were used for the PCR.

\subsection{Amplification conditions}

The canine Slc1lal gene was PCR amplified in nine different fragments, encompassing the promoter region, the 5' and 3' untranslated region (UTR), the 15 exons, and partially the introns. PCR primers were designed with Primer Express software v 2.0 (Applied-Biosystems, Foster City, CA, USA). The PCR conditions (two different enzymes and commercial kits) and the thermocycling profiles used are shown in Table II. For the GC-rich PCR amplification system (Roche, Basel, Switzerland), the PCR was performed in a final volume of $25 \mu \mathrm{L}$ containing $10-20 \mathrm{ng}$ of genomic DNA, $1.5 \mathrm{mM} \mathrm{MgCl} 2,200 \mu \mathrm{M}$ of each dNTP, primer concentration shown in Table II, 0.5 M GC rich resolution solution, and $2 \mathrm{U}$ of Taq and Tgo DNA polymerase mix. Thermal cycling profile was $95^{\circ} \mathrm{C}$ for $3 \mathrm{~min}$ followed by $35 / 40$ cycles at $94^{\circ} \mathrm{C}$ for $45 \mathrm{~s}$, $55 / 56^{\circ} \mathrm{C}$ for $45 \mathrm{~s}, 72{ }^{\circ} \mathrm{C}$ for $1 \mathrm{~min}$ with a final extension at $72{ }^{\circ} \mathrm{C}$ for $10 \mathrm{~min}$. The PCR with EcoTaq polymerase (Ecogen, Barcelona, Spain) was carried out in a final volume of $20 \mu \mathrm{L}$ containing $10-20 \mathrm{ng}$ of genomic DNA, $1.5 \mathrm{mM} \mathrm{MgCl} 2,200 \mu \mathrm{M}$ of each dNTP, primer concentration shown in Table II and $1 \mathrm{U}$ of Taq polymerase. The thermal cycling profile was $95^{\circ} \mathrm{C}$ for $3 \mathrm{~min}$ followed by 35 cycles at $94^{\circ} \mathrm{C}$ for $45 \mathrm{~s}, 63^{\circ} \mathrm{C}$ for $45 \mathrm{~s}, 72^{\circ} \mathrm{C}$ for 1 min with a final extension at $72^{\circ} \mathrm{C}$ for $10 \mathrm{~min}$. All amplifications were performed in a PTC-200 MJ Research (Bio-Rad Laboratories, Hercules, CA, USA). 


\begin{tabular}{|c|c|c|c|c|c|c|c|}
\hline Region & $\begin{array}{l}\text { Position } \\
\text { (nt) }\end{array}$ & $\begin{array}{l}\text { PCR primers } \\
\left(5^{\prime}-3^{\prime}\right)\end{array}$ & $\begin{array}{l}\text { PCR } \\
\text { product } \\
(\mathrm{bp})\end{array}$ & $\begin{array}{c}\text { Primer } \\
(\mu \mathrm{M}) \\
\text { Anneal }\end{array}$ & $\begin{array}{c}\text { Enzyme }^{4} \\
\text { Cycles }\end{array}$ & $\begin{array}{l}\text { Target } \\
\left(5^{\prime}-3^{\prime}\right)\end{array}$ & Snapshot primers \\
\hline \multirow[t]{2}{*}{$\overline{\mathrm{PR}}$} & $28-566$ & ${ }^{1}$ CCTCTCAGCTAGTCTGAGCC & 539 & 0.2 & A & $\begin{array}{l}\text { T151C } \\
\text { A180G }\end{array}$ & Direct sequencing \\
\hline & & ${ }^{2}$ CAGCTGATCTCAGCTGTCCTC & & $55^{\circ} \mathrm{C}$ & 35 & $\begin{array}{c}\text { G318A } \\
\text { Gstretch-321 }\end{array}$ & \\
\hline PR-I2 & $28-1641$ & $\begin{array}{l}\text { CCTCTCAGCTAGTCTGAGCC } \\
\text { CATCCTGTCAATCCTGAAGG }\end{array}$ & 1588 & $\begin{array}{l}0.3 \\
63^{\circ} \mathrm{C}\end{array}$ & $\begin{array}{c}\mathrm{B} \\
35\end{array}$ & A739G & $(\mathrm{AT})^{1}$ ACTGACTCTCCCCGCCTCC \\
\hline I1 & $\begin{array}{l}1185- \\
1308\end{array}$ & ${ }^{3}$ GAGTCTGCTTGAGATTCTCTC & $133 / 145$ & 0.2 & B & $\mu$ sat 1253 & Capillar electrophoresis \\
\hline \multirow[t]{2}{*}{ I2-I6 } & $\begin{array}{l}2251- \\
4444\end{array}$ & $\begin{array}{l}\text { TATCACCTCCACCCTTCAAAC } \\
\text { GAACGGAATGAGTGCAGGGC }\end{array}$ & 2173 & $\begin{array}{c}55^{\circ} \mathrm{C} \\
0.3\end{array}$ & $\begin{array}{l}25 \\
\mathrm{~B}\end{array}$ & $\mathrm{C} 2336 \mathrm{~T}$ & $(\mathrm{AT})^{6} \mathrm{AAAGGCCCACTGCTCCCAG}$ \\
\hline & & ATCCCCGTGGTGTAGACGAAG & & $63^{\circ} \mathrm{C}$ & 35 & $\begin{array}{l}\text { T2588C } \\
\text { G3920T }\end{array}$ & $\begin{array}{l}(\mathrm{AT})^{7} \text { ACGTTTATGGCCCATTTGAACCT } \\
(\mathrm{AT})^{11} \text { AGGTGGCAAGCATCTGAGACA }\end{array}$ \\
\hline I3-I4 & $\begin{array}{l}2622- \\
2948\end{array}$ & ${ }^{3}$ CTGCCCTACCAGGGTGCA & 347 & 0.3 & B & In2724del & Capillar electrophoresis \\
\hline \multirow[t]{2}{*}{ I6-E9 } & $\begin{array}{l}4461- \\
5786\end{array}$ & $\begin{array}{l}\text { AGCTGTACATGGCTGTTTGGG } \\
\text { GGATGCTCCTAGCACAGATGC }\end{array}$ & 1304 & $\begin{array}{c}63^{\circ} \mathrm{C} \\
0.3\end{array}$ & $\begin{array}{l}35 \\
\mathrm{~B}\end{array}$ & A4549G & $(\mathrm{AT})^{9}$ ACCGGTTAGTGGCCAATATCTCTAG \\
\hline & & GGTAGAAGGCCTGCCCGAA & & $63^{\circ} \mathrm{C}$ & 35 & $\begin{array}{l}\text { C4580T } \\
\text { C4859T }\end{array}$ & $\begin{array}{l}\text { (AT) }{ }^{10} \text { ACACAGTAGCAACAACAACAAAAATTGTA } \\
\left(\text { AT) }{ }^{6} \text { AGTACGTGGTGGCACGTCC }\right.\end{array}$ \\
\hline I9-E11 & $\begin{array}{l}6738- \\
7083\end{array}$ & AATTCTTCCCCAATCTGAGCC & 411 & 0.3 & B & C6828G & $(\mathrm{AT})^{8}$ AGACTGTACCCTGTACCGGGC \\
\hline \multirow[t]{2}{*}{ I11-E13 } & $\begin{array}{l}7482- \\
8232\end{array}$ & $\begin{array}{l}\text { AAGACGCAGCCCAGCATCAC } \\
\text { CCACTAGGGTCAGAGCTACCC }\end{array}$ & 711 & $\begin{array}{l}63^{\circ} \mathrm{C} \\
0.4\end{array}$ & $\begin{array}{l}35 \\
\mathrm{~A}\end{array}$ & $\begin{array}{l}\text { C6920T } \\
\text { C7623T }\end{array}$ & $\begin{array}{l}\text { (AT) }{ }^{1} \text { AGCAGACGTTGAACTGCGG } \\
(\text { AT })^{10} \text { CCACCACCAAAGTGCCCA }\end{array}$ \\
\hline & & CGTAAGGATAGGCAGCACCGC & & $56^{\circ} \mathrm{C}$ & 40 & $\begin{array}{c}\text { C7626T } \\
\text { G7715A } \\
\text { T7825Del } \\
\text { G7910A } \\
\text { A7931T } \\
\text { G8035C }\end{array}$ & $\begin{array}{l}(\mathrm{AT})^{7} \text { AGAAGCCCTGGGGGAGG } \\
\text { (AT) })^{2} \text { ACCTGCCCACCGTGCTC } \\
\text { (AT) }{ }^{11} \text { AGACACCTGCGGTTCTGCTT } \\
\text { (AT) })^{13} \text { ACCACCTTGCCTCTAAGGCTCTC } \\
\text { (AT) }{ }^{10} \text { CTGCCCAGTGGGGACAG } \\
\text { (AT) }{ }^{7} \text { ACCAGAGAGCCCCGCAA }\end{array}$ \\
\hline I13-3'UTR & $\begin{array}{l}8401- \\
9460\end{array}$ & TTAAGCAACGTGTGCAAGGG & 1060 & 0.4 & A & $\mathrm{C} 8542 \mathrm{~T}$ & $(\mathrm{AT})^{4}$ GAGGGCCGGGGGG \\
\hline
\end{tabular}




\subsection{SNP characterization}

Characterization of polymorphism has been accomplished by direct sequencing of $7110 \mathrm{bp}$ from the Slcllal gene in 40 dogs from 11 different breeds (Tab. I). The gene partial sequence comprises the promoter region, the 5' and 3' UTRs, the 15 exons and all the intron-exon boundaries. Sequence was completed for introns $1,3,5$, 6, 7, 12 and 14, and only partially completed for the remaining introns. The PCR products were purified and sequenced with the same PCR primers using Ready Reaction Cycle Sequencing Kit ABI PRISM Big-Dye Terminator v3.1 and dGTP Terminator v3.0 for the promoter region in an ABI 3730 DNA Analyzer (Applied-Biosystems). All the SNP were named in relation to the published canine Slc1 lal gene sequence ( 9490 bp, GenBank, Accession number AF091049) [1], in which the translational start codon is located at position 689 of the sequence.

\subsection{Polymorphism analyses}

Polymorphism analyses previously described in the promoter region [23] were accomplished by direct sequencing of a $539 \mathrm{bp}$ PCR product (PR, Tab. II) after purification with Montage Seq96 Sequencing Reaction Cleanup Kit (Millipore, Billerica, MA, USA). Intron 1 microsatellite ( $\mu$ sat1253) [23] and intron 3 indel (In2724del) (Tab. II) were analyzed by capillary electrophoresis (ABI 3730 DNA Analyzer). Labeled PCR products were automatically sized relative to the internal standard CST ROX 70-500 (BioVentures, Murfreesboro, TN, USA) with the Genemapper Software v.3.5 (Applied-Biosystems). Other exonic and intronic SNP were identified by primer extension using SNapShot kit in a GeneAmp 9700 Thermal Cycler and by capillary electrophoresis using the internal standard GeneScan-Liz-120TM with the Genemapper Software v.3.7 (AppliedBiosystems).

\subsection{Statistical analysis}

Data analyses for bi- and multiallelic polymorphisms were performed with SNPator (http:// www.snpator.org/public/principal/index.php) and GENEPOP genetics software package (Laboratoire de Génétique et Environnement, Montpellier, France), respectively [20]. The association study applied contingency tables assuming different genetic models: (i) general, (ii) recessive, (iii) codominant and (iv) dominant. Haplotypes from our population data were inferred with PHASE $\mathrm{v}$ 2.1 program (University of Washington, Seattle, WA, USA) [30, 31], and the five most frequent haplotypes were confirmed by trio-family based analysis in Boxer, Doberman Pinscher, German Shepherd, Rottweiler and Teckel breeds. Association analyses were performed in the extended case-control cohort (data not shown) and in a reduced, fully matched cohort (47 cases versus 47 controls in a 1:1 ratio), chosen at random from the available dogs, to confirm the significant associations.

Statistical differences between case and control group were initially tested for significance by chi-square analysis or Fisher exact test with the Haldane correction. After producing a fully matched dataset, data were analysed by means of a matched case-control test making use of logistic regressions [16]. The risk factor in case vs control computing odds ratios (OR) with $95 \%$ confidence interval was evaluated. A $p$-value $<0.05$ was regarded as statistically significant. Significance levels or patterns did not differ between analysis (Tab. A, supplemental data available online at www.vetres.org), thus confirming the validity of the reported associations.

\subsection{Identification of transcription factor binding sites and exon/intron splicing signals}

For the analysis of DNA sequences of known eukaryotic signals we used SIGNAL SCAN Genetic Sequence Analysis Software (National University of Singapore, Singapore) [33]. To identify putative exonic (ESE) and intronic (ISE) splicing enhancers the web-based resources called ESEfinder release 3.0 and ACESCAN2 (ACESCAN2 Web Server, http://genes.mit.edu/acescan2/index.html) were applied, respectively $[6,27]$.

\section{RESULTS}

\subsection{Slc11a1: characterization of new polymorphism and genotyping of the case-control cohort}

Sequencing of $7110 \mathrm{bp}$ from the whole $9490 \mathrm{bp}$ of Slc1lal gene in 40 dogs from 11 different breeds allowed the characterization of 19 new polymorphisms in the Slcllal gene 
Table III. Results of genotypic association test for the SNP significantly associated with CVL for the breed matched cohort assuming different genetic models: ${ }^{1}$ general, ${ }^{2}$ recessive, ${ }^{3}$ codominant, and ${ }^{4}$ dominant. $* p$-value $<0.05 ; * *$-value $<0.01 .{ }^{5}$ Risk Genotype corresponds to the genotype positively associated with cases. ${ }^{+}$relevant odds ratio.

\begin{tabular}{|c|c|c|c|c|}
\hline SNP & Risk genotype $^{5}$ & Odds ratio & $95 \% \mathrm{CI}$ & $p$-value \\
\hline \multirow{4}{*}{$\overline{\mathrm{A} 4549 \mathrm{G}}$} & $\mathrm{AG}^{1}$ & - & - & $0.003 * *$ \\
\hline & $\mathrm{GG}^{2}$ & $5.29^{+}$ & $1.05-26.68$ & $0.024 *$ \\
\hline & $\mathrm{AG}^{3}$ & $5.29^{+}$ & $1.05-26.68$ & $0.024 *$ \\
\hline & $\mathrm{AG}+\mathrm{GG}^{4}$ & $6.78^{+}$ & $2.02-22.76$ & $0.001 * *$ \\
\hline \multirow[t]{4}{*}{$\mathrm{C} 4859 \mathrm{~T}$} & $\mathrm{TT}^{1}$ & - & - & $0.001 * *$ \\
\hline & $\mathrm{TT}^{2}$ & 10.68 & $0.56-204.85$ & 0.119 \\
\hline & $\mathrm{CT}^{3}$ & $8.68^{+}$ & $1.81-41.77$ & $0.003 * *$ \\
\hline & $\mathrm{CT}+\mathrm{TT}^{4}$ & $13.44^{+}$ & $2.85-63.39$ & $0.004 * *$ \\
\hline \multirow[t]{4}{*}{$\mathrm{C} 8542 \mathrm{~T}$} & $\mathrm{TT}^{1}$ & - & - & $0.018^{*}$ \\
\hline & $\mathrm{TT}^{2}$ & 1.44 & $0.60-3.49$ & 0.359 \\
\hline & $\mathrm{CC}+\mathrm{TT}^{3}$ & $10.5+$ & $1.27-86.9$ & 0.098 \\
\hline & $\mathrm{CC}^{4}$ & 1.45 & $0.63-3.37$ & 0.366 \\
\hline
\end{tabular}

(Tab. I): two SNP were located in the coding region (exons 8 and 12) and represent silent mutations, 15 SNP and a 14 bp deletion were identified in intronic regions and one SNP in the 3'UTR. These new polymorphisms, together with the three SNP and the G-stretch in the promoter and the microsatellite in intron 1, have been analyzed in the casecontrol cohort of 164 dogs from 19 different breeds and the Ibizan Hound cohort of 58 dogs (Tab. I).

\subsection{Association study with CVL}

Results of genotypic association tests for the biallelic polymorphisms analyzed in the canine Slcllal gene significantly associated with CVL are described in Table III. Since Hardy-Weinberg equilibrium does not hold in our case-control cohort, only genotypic associations are presented to avoid bias in allelic associations. Genotype distribution for the polymorphisms significantly associated with CVL is shown in Table IV for the case-control cohort and for the Ibizan Hound cohort. Allele frequencies distribution for the most representative breeds is shown in Table V.

The significant genotypic association between promoter SNP and CVL is corroborated in the extended cohort for two (A180G: $\mathrm{OR}=11.63, \quad P=0.039 ; \quad \mathrm{G} 318 \mathrm{~A}$ :
$\mathrm{OR}=11.63, P=0.039)$ of the three SNP, although they have not been identified in new dogs. These SNP had been identified in German Shorthair Pointer, Doberman Pinscher, Rottweiler and German Shepherd. Risk allele $\mathrm{G}$ in SNP A180G disrupts one potential SOX9 binding site (CATCAATGC) and risk allele A in SNP G318A interferes with four different potential binding sites for transcription factors: one SPI1 (CGGATG); one SP1 (GTGGGGCGGA; involved in the regulation of mRNA synthesis); one GATA2 (GGATG; which is an endothelial transcription factor); and one RREB1 $\left(\mathrm{C}_{5}\right.$ ATCCGC ${ }_{4}$ ACACAA; which acts as RASresponsive element-binding protein). These significant associations are lost in the reduced fully matched cohort.

Among the 19 new polymorphisms identified we discovered significant genotypic associations with CVL for three SNP: C4859T in exon $8(\mathrm{OR}=13.44 ; P=0.004), \mathrm{A} 4549 \mathrm{G}$ in intron $6(\mathrm{OR}=6.78 ; P=0.001)$ and $\mathrm{C} 8542 \mathrm{~T}$ in intron $13(P=0.018)$. The significance is maintained assuming different genetic models for the SNP C4859T and A4549G but significance for the SNP C8542T is marginal and only obtained in one model (Tab. III).

For the case-control population 22 haplotypes were inferred with PHASE. Significant differences in haplotype frequency between 
Table IV. Genotype and allele frequencies of the Slc1 lal gene SNP significantly associated with CVL for the breed matched cohort and for the Ibizan Hound cohort. $N$ : is the number of alleles.

\begin{tabular}{llccccc}
\hline SNP & \multicolumn{3}{c}{ Genotype } & \multicolumn{3}{c}{ Allele } \\
\hline A4549G & AA & AG & GG & A & G & $N$ \\
Case & 0.59 & 0.21 & 0.20 & 0.69 & 0.31 & 94 \\
Control & 0.88 & 0.05 & 0.07 & 0.92 & 0.08 & 94 \\
Ibizan Hound & 0.82 & 0.16 & 0.02 & 0.90 & 0.10 & 90 \\
C4859T & CC & CT & TT & C & T & \\
Case & 0.62 & 0.29 & 0.09 & 0.76 & 0.24 & 94 \\
Control & 0.93 & 0.07 & - & 0.97 & 0.03 & 94 \\
Ibizan Hound & 0.79 & 0.21 & - & 0.89 & 0.11 & 94 \\
C8542T & CC & CT & TT & C & T & \\
Case & 0.59 & 0.02 & 0.39 & 0.60 & 0.40 & 94 \\
Control & 0.49 & 0.19 & 0.32 & 0.59 & 0.41 & 94 \\
Ibizan Hound & 1.00 & - & - & 1.00 & - & 114 \\
\hline
\end{tabular}

cases and controls have been observed in an overall test $(P=0.01)$. The five most frequent haplotypes, confirmed by trio-family based analysis, were included in the association study (Tab. VI). Only one Slcllal haplotype (D), which included the risk alleles for the SNP A4549G (intron 6) and C4859T (exon 8) was significantly associated with CVL $(\mathrm{OR}=8.81 ; P=0.01)$ and was identified in Miniature and Standard Schnauzers as well as in Siberian Huskies. Six haplotypes for the Ibizan Hound cohort, inferred with PHASE since no genealogy information was available, seemed to be specific for this breed (Tab. VI).

\section{DISCUSSION}

In humans, several studies have demonstrated that Slcllal is associated with susceptibility to visceral leishmaniasis, and that a functional polymorphism in the promoter correlated with infectious and autoimmune disease susceptibility $[2,3,9,17,25,35]$. Although associations had also been described in the dog between this gene and canine visceral leishmaniasis (CVL) [1, 19, 23], the current study further characterized the canine Slcllal gene and attempted to determine the genetic susceptibility to Leishmania infection among dogs and the risk for CVL. Sequencing the canine Slcllal gene, we identified 19 new polymorphisms among 40 dogs from
11 different breeds and we analyzed them in 164 dogs from 19 different breeds in a case-control study and a cohort of 58 Ibizan Hounds, a breed that has been described as resistant to CVL [28]. Data analysis revealed that three of the 24 polymorphisms found in the Slcllal gene were associated with increased risk for CVL.

Two single nucleotide polymorphisms (SNP) (A180G and G318A) in the Slc1lal promoter region were found to be significantly associated with increased risk for CVL in the extended case-control population, as was previously described [23] (Tab. III). These SNP involve putative transcription binding sites that are disrupted by the risk-alleles (SOX9 for A180G; SPI, SP1, GATA2 and RREB1 for G318A). In humans, a polymorphism in the promoter of Slcllal encodes a Z-DNA forming dinucleotide repeat with four alleles, which differ in their ability to drive gene expression, and thus some alleles have been associated with resistance/susceptibility to infectious and autoimmune diseases [25]. The fact that the two SNP in the canine Slcllal gene promoter disrupted putative transcription factor binding sites suggests a possible role of differential Slcllal gene expression in CVL susceptibility.

Regarding the new 19 SNP described in the exonic and intronic regions of the canine 
Table V. Allele frequencies distribution for the most representative breeds of the Slc1lal gene SNP significantly associated to CVL from the extended case-control cohort; (cs) case; (ct) control dogs. Breeds with $N<4$ were omitted.

\begin{tabular}{|c|c|c|c|c|c|c|c|c|}
\hline \multirow[t]{2}{*}{ Breed } & & \multirow[b]{2}{*}{$N$} & \multicolumn{2}{|c|}{ A4549G } & \multicolumn{2}{|c|}{$\mathrm{C} 4859 \mathrm{~T}$} & \multicolumn{2}{|c|}{$\mathrm{C} 8542 \mathrm{~T}$} \\
\hline & & & $\overline{\mathrm{A}}$ & $\mathrm{G}$ & $\mathrm{C}$ & $\mathrm{T}$ & $\mathrm{C}$ & $\mathrm{T}$ \\
\hline Ibizan Hound & & 58 & 1.00 & - & 1.00 & - & 1.00 & - \\
\hline \multirow[t]{2}{*}{ Boxer } & $\mathrm{cs}$ & 12 & 1.00 & - & 1.00 & - & - & 1.00 \\
\hline & ct & 23 & 1.00 & - & 1.00 & - & 0.14 & 0.86 \\
\hline \multirow[t]{2}{*}{ German Sheperd } & $\mathrm{cs}$ & 9 & 0.90 & 0.10 & 0.92 & 0.08 & 1.00 & - \\
\hline & ct & 20 & 0.95 & 0.05 & 0.97 & 0.03 & 0.85 & 0.15 \\
\hline \multirow[t]{2}{*}{ Siberian Husky } & cs & 3 & 0.67 & 0.33 & 0.50 & 0.50 & 1.00 & - \\
\hline & $\mathrm{ct}$ & 7 & 0.88 & 0.12 & 0.80 & 0.20 & 1.00 & - \\
\hline \multirow[t]{2}{*}{ Beagle } & cs & 4 & 1.00 & - & 1.00 & - & 1.00 & - \\
\hline & ct & 3 & 1.00 & - & 1.00 & - & 1.00 & - \\
\hline \multirow[t]{2}{*}{ Great Dane } & $\mathrm{cs}$ & 2 & 0.75 & 0.25 & 0.50 & 0.50 & 0.33 & 0.67 \\
\hline & ct & 2 & 0.83 & 0.17 & 0.83 & 0.17 & 0.33 & 0.67 \\
\hline \multirow[t]{2}{*}{ Rottweiler } & cs & 2 & - & 1.00 & 0.75 & 0.25 & 1.00 & - \\
\hline & $\mathrm{ct}$ & 14 & 0.46 & 0.54 & 0.96 & 0.04 & 1.00 & - \\
\hline \multirow[t]{2}{*}{ Foxhound } & $\mathrm{cs}$ & 10 & 0.80 & 0.20 & 0.80 & 0.20 & 1.00 & - \\
\hline & ct & 2 & 1.00 & - & 1.00 & - & 1.00 & - \\
\hline \multirow[t]{2}{*}{ Miniature Schnauzer } & cs & 3 & - & 1.00 & 0.12 & 0.88 & 0.67 & 0.33 \\
\hline & ct & 1 & 1.00 & - & 1.00 & - & 0.65 & 0.35 \\
\hline \multirow[t]{2}{*}{ Standard Schnauzer } & cs & 3 & - & 1.00 & - & 1.00 & 0.70 & 0.30 \\
\hline & $\mathrm{ct}$ & 3 & 1.00 & - & 1.00 & - & 0.63 & 0.37 \\
\hline \multirow[t]{2}{*}{ Doberman Pinscher } & cs & 2 & 0.75 & 0.25 & 1.00 & - & 0.50 & 0.50 \\
\hline & ct & 6 & 0.75 & 0.25 & 1.00 & - & 0.75 & 0.25 \\
\hline \multirow[t]{2}{*}{ Bulldog } & cs & 2 & 1.00 & - & 1.00 & - & 1.00 & - \\
\hline & ct & 4 & 1.00 & - & 1.00 & - & 1.00 & - \\
\hline \multirow[t]{2}{*}{ Cocker Spaniel } & cs & 2 & 1.00 & - & 1.00 & - & 0.75 & 0.25 \\
\hline & $\mathrm{ct}$ & 4 & 1.00 & - & 1.00 & - & 0.25 & 0.75 \\
\hline \multirow[t]{2}{*}{ Teckel } & cs & 1 & 0.50 & 0.50 & 0.50 & 0.50 & - & 1.00 \\
\hline & ct & 4 & 0.34 & 0.66 & 0.50 & 0.50 & - & 1.00 \\
\hline \multirow[t]{2}{*}{ Pointer } & cs & 1 & - & 1.00 & 0.50 & 0.50 & - & 1.00 \\
\hline & $\mathrm{ct}$ & 3 & 0.83 & 0.17 & 0.83 & 0.17 & 0.67 & 0.33 \\
\hline
\end{tabular}

Slcllal gene, we found significant association with CVL for three of them: A4549G (intron 6), C4859T (exon 8) and C8542T (intron 13) (Tab. III). Moreover, one haplotype that was significantly associated with CVL was haplotype (D), which included the risk alleles for the SNP A4549G and C4859T mentioned above (Tab. VI).

Despite affecting non-coding region, intronic SNP could be linked to the causal mutation or have functional effects by themselves. In fact, a human family-based allelic association test revealed that intron $4469+14 \mathrm{G} / \mathrm{C}$ polymorphism in the human Slcllal gene is associated with increased susceptibility to leishmaniasis, probably due to a linkage disequilibrium between this polymorphism and an additional SNP upstream in the promoter [17]. Furthermore, intronic regulatory elements, such as intronic

Page 8 of 12 (page number not for citation purpose) 
Table VI. (A) Haplotype confirmed by trio-based family in the matched case-control population and association test with CVL for all the polymorphisms described in the Slc1lal gene. * $p$-value $<0.05 ; * *$-value $<0.01 ;{ }^{+}$Haldane correction applied; (B) Haplotype estimation for the Ibizan Hound cohor (IB). Haplotypes with a frequency of $N<5$ have been discarded. $N$ : number of dogs that present certain haplotype. ${ }^{1} \mathrm{D}$ : deletion (14 bp); ND: no deletion; ${ }^{2}$ D: deletion ( $\left.1 \mathrm{bp}\right)$, T: no deletion. Data in bold are discussed in the text.

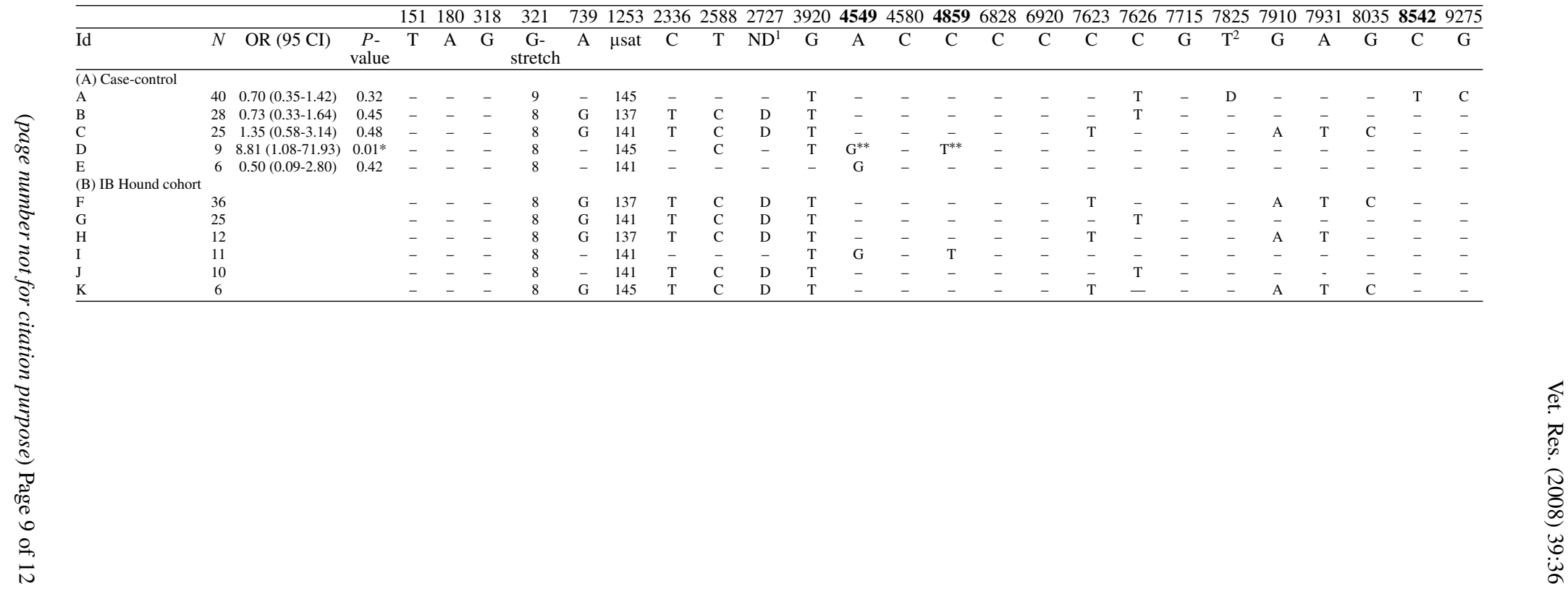


splicing enhancers/silencers (ISE/ISS) [32], are involved in the pre-mRNA splicing and, therefore, affect the mature mRNA and consequently the protein product.

The polymorphism found in the exon 8 (C4859T) represents a synonymous mutation that changes the codon CCC (Pro) to CCT (Pro). Synonymous SNP do not alter the coding sequence, and, therefore, they are not expected to change the function of the resulting protein. However, the protein folding could be affected due to changes in the translation rate caused by the use of a rare codon [15], and this effect is larger if the change involves the third base in a codon as is the case here [34]. Corroborating data for this hypothesis is that a silent mutation in a complex mammalian membrane transport protein alters the substrate specificity [6]. It should be noted that the SNP in exon 8 (C4859T) is not located in a predicted transmembrane segment (TMS), but the residue encoded by the triplet that contains the SNP could affect cation transport and thereby divalent metal ions uptake [7].

Moreover, there is increasing evidence that many genes causing human disease harbour exonic mutations, without altering the amino acid sequence, but affecting pre-mRNA splicing [5]. These exonic polymorphisms, identified as splicing mutations, are located close to the exon-intron boundaries and can act as enhancers or silencers elements. The inactivation of an exonic splicing enhancer (ESE) can result in a partial or complete exon skipping, and can thereby markedly affect the structure or amount of the expressed protein product [5]. The risk allele in the exon 8 (C4859T) disrupts a putative ESE that is recognized by the serine/arginine-rich (SR) protein SF2/ASF (IgM-BRCA1) [27]. Functional analyses at cDNA level would be necessary to confirm the effect of these exonic/intronic splicing regulatory elements in the canine Slc1lal gene. In fact, alternative splicing with a complete exon 11 skipping thereby resulting in elimination of TM8 has been described in the Slcllal gene of a dog affected with relapsing CVL [1].
The Ibizan Hound breed has been reported to be resistant to CVL due to its strong cellular response to the infection [28]. In the Ibizan Hound cohort no dog has been affected with CVL, and, interestingly, six Slcllal haplotypes appear to be specific to this breed. The high number of haplotypes found in this autochtonous breed on an island is surprising, considering the expected high rate of inbreeding. Similarly in a recent survey of 937 dogs from 80 different breeds a high number of haplotypes for the MHC class II genes were found in Ibizan Hound, albeit two appear to be unique in this breed [14]. The genetic resistance against CVL in the Ibizan Hound may be shared with other breeds supposed to be resistant to CVL, such as the Pharaoh dog (Ferrer L., personal communication).

In conclusion, our data show that the new polymorphisms found in intron 6 (A4549G), exon 8 (C4859T) and intron 13 (C8542T) and a certain haplotype that included the risk alleles for two of them are associated with increased risk for CVL. This genetic component is likely to be caused by the expression and function of Slc1lal and its interaction with multiple other genes.

Acknowledgements. This work was supported by the Veterinary Molecular Genetic Service from the Universitat Autònoma de Barcelona, by the Spanish National Institute for Bioinformatics (www.inab.org), a Platform of Genoma España and by a grant from the National Institutes of Health \#RR02512.

We are thankful to the Veterinary Teaching Hospital from the Universitat Autònoma de Barcelona and all the clinician veterinarians for providing the samples used in this study. We are also thankful to the anonymous referees for their critical review.

\section{REFERENCES}

[1] Altet L., Francino O., Solano-Gallego L., Renier C., Sánchez A., Mapping and sequencing of the canine NRAMP1 gene and identification of mutations in leishmaniasis-susceptible dogs, Infect. Immun. (2002) 70:2763-2771.

[2] Blackwell J., Mohamed H., Ibrahim M., Genetics and visceral leishmaniasis in the Sudan: seeking a link, Trends Parasitol. (2004) 20:268-274.

[3] Bucheton B., Abel L., Kheir M., Mirgani A., ElSafi S., Chevillard C., Dessein A., Genetic control 
of visceral leishmaniasis in a Sudanese population: candidate gene testing indicates a linkage to the NRAMP1 region, Genes Immun. (2003) 4:104-109.

[4] Burgner D., Jamieson S., Blackwell J., Genetic susceptibility to infectious diseases: big is beautiful, but will bigger be even better? Lancet Infect. Dis (2006) 6:653-663.

[5] Cartegni L., Chew S., Krainer A., Listening to silence and understanding nonsense: exonic mutations that affect splicing, Nat. Rev. Genet. (2002) 3:285298.

[6] Cartegni L., Wang J., Zhu Z., Zhang M., Krainer A., ESEfinder: a web resource to identify exonic splicing enhancers, Nucleic Acids Res. (2003) 31:3568-3571.

[7] Courville P., Chaloupka R., Cellier M., Recent progress in structure-function analyses of Nramp proton-dependent metal-ion transporters, Biochem. Cell Biol. (2006) 84:960-978.

[8] Duprey Z., Steurer F., Rooney J., Kirchhoff L. Jackson J., Rowton E., Schantz P., Canine visceral leishmaniasis, United States and Canada, 2000-2003, Emerging Infect. Dis. (2006) 12:440-446.

[9] El-Safi S., Kheir M., Bucheton B., Argiro L., Abel L., Dereure J., et al., Genes and environment in susceptibility to visceral leishmaniasis, C. R. Biol. (2006) 329:863-870

[10] Enserink M., Infectious diseases. Has leishmaniasis become endemic in the USA?, Science (2000) 290:1881-1883.

[11] França-Silva J., da Costa R., Siqueira A., Machado-Coelho G., da Costa C., Mayrink W., et al., Epidemiology of canine visceral leishmaniosis in the endemic area of Montes Claros Municipality, Minas Gerais State, Brazil, Vet.Parasitol. (2003)111:161-173.

[12] Gaskin A., Schantz P., Jackson J., Birkenheuer A., Tomlinson L., Gramiccia M., et al., Visceral leishmaniasis in a New York foxhound kennel, J. Vet. Intern. Med. (2002) 16:34-44.

[13] Gruenheid S., Pinner E., Desjardins M., Gros P., Natural resistance to infection with intracellular pathogens: the Nramp1 protein is recruited to the membrane of the phagosome, J. Exp. Med. (1997) $185: 717-730$

[14] Kennedy L., Barnes A., Short A., Brown J., Lester S., Seddon J., et al., Canine DLA diversity: 1. New alleles and haplotypes, Tissue Antigens (2007) 69S1:272-288.

[15] Kimchi-Sarfaty C., Oh J., Kim I., Sauna Z. Calcagno A., Ambudkar S., Gottesman M., A "silent" polymorphism in the MDR1 gene changes substrate specificity, Science (2007) 315:525-528.
[16] McNeil D., Epidemiological research methods, John Wiley and Sons, New York, 1996.

[17] Mohamed H., Ibrahim M., Miller E., White J., Cordell H., Howson J., et al., SLC11A1 (formerly NRAMP1) and susceptibility to visceral leishmaniasis in The Sudan, Eur. J. Hum. Genet. (2004) 12:66-74.

[18] Owens S., Oakley D., Marryott K., Hatchett W., Walton R., Nolan T., et al., Transmission of visceral leishmaniasis through blood transfusions from infected English foxhounds to anemic dogs, J. Am. Vet. Med. Assoc. (2001) 219:1076-1083.

[19] Quinnell R., Kennedy L., Barnes A., Courtenay O., Dye C., Garcez L., et al., Susceptibility to visceral leishmaniasis in the domestic dog is associated with MHC class II polymorphism, Immunogenetics (2003) 55:23-28.

[20] Raymond M., Rousset F., GENEPOP (version 1.2): population genetics software for exact tests and ecumenicism, J. Hered. (1995) 86:248-249.

[21] Rosypal A., Zajac A., Lindsay D., Canine visceral leishmaniasis and its emergence in the United States, Vet. Clin. North Am. Small Anim. Pract. (2003) 33:921-937.

[22] Roura X., Sánchez A., Ferrer L., Diagnosis of canine leishmaniasis by a polymerase chain reaction technique, Vet. Rec. (1999) 144:262-264.

[23] Sanchez-Robert E., Altet L., Sanchez A., Francino O., Polymorphism of Slc11a1 (Nramp1) gene and canine leishmaniasis in a case-control study, J. Hered. (2005) 96:755-758.

[24] Schantz P., Steurer F., Duprey Z., Kurpel K., Barr S., Jackson J., et al., Autochthonous visceral leishmaniasis in dogs in North America, J. Am. Vet. Med. Assoc. (2005) 226:1316-1322.

[25] Searle S., Blackwell J., Evidence for a functional repeat polymorphism in the promoter of the human NRAMP1 gene that correlates with autoimmune versus infectious disease susceptibility, J. Med. Genet. (1999) 36:295-299.

[26] Shaw S., Lerga A., Williams S., Beugnet F., Birtles R., Day M., Kenny M., Review of exotic infectious diseases in small animals entering the United Kingdom from abroad diagnosed by PCR, Vet. Rec. (2003) 152:176-177.

[27] Smith P., Zhang C., Wang J., Chew S., Zhang M., Krainer A., An increased specificity score matrix for the prediction of SF2/ASF-specific exonic splicing enhancers, Hum. Mol. Genet. (2006) 15: 2490-2508.

[28] Solano-Gallego L., Llull J., Ramos G., Riera C., Arboix M., Alberola J., Ferrer L., The Ibizan hound presents a predominantly cellular immune response 
Vet. Res. (2008) 39:36

against natural Leishmania infection, Vet. Parasitol. (2000) 90:37-45.

[29] Solano-Gallego L., Morell P., Arboix M., Alberola J., Ferrer L., Prevalence of Leishmania infantum infection in dogs living in an area of canine leishmaniasis endemicity using PCR on several tissues and serology, J. Clin. Microbiol. (2001) 39:560-563.

[30] Stephens M., Donnelly P., A comparison of bayesian methods for haplotype reconstruction from population genotype data, Am. J. Hum. Genet. (2003) 73:1162-1169.

[31] Stephens M., Smith N., Donnelly P., A new statistical method for haplotype reconstruction from population data, Am. J. Hum. Genet. (2001) 68:978-989.
E. Sanchez-Robert et al.

[32] Tazi J., Durand S., Jeanteur P., The spliceosome: a novel multi-faceted target for therapy, Trends Biochem. Sci. (2005) 30:469-478.

[33] Wingender E., Chen X., Hehl R., Karas H., Liebich I., Matys V. et al., TRANSFAC: an integrated system for gene expression regulation, Nucleic Acids Res. (2000) 28:316-319.

[34] Xie T., Ding D., Tao X., Dafu D., The relationship between synonymous codon usage and protein structure, FEBS Lett. (1998) 434:93-96.

[35] Zaahl M., Robson K., Warnich L., Kotze M., Expression of the SLC11A1 (NRAMP1) 5'-(GT)n repeat: opposite effect in the presence of $-237 \mathrm{C} \rightarrow \mathrm{T}$, Blood Cells Mol. Dis. (2004) 33:45-50. 